\title{
A study of poisonous plants of Balochistan, Pakistan
}

\author{
Abdul Hameed Baloch ${ }^{1}$, Iftekhar Ahmed Baloch ${ }^{2 *}$, Hanif-ur-Rehman ${ }^{3}$, \\ Imtiaz Ahmed ${ }^{4}$ and Saeed Ahmed ${ }^{4}$ \\ 1. Faculty of Agriculture, LUAWMS, Uthal Balochistan-Pakistan \\ 2. Govt. Degree College Khanozai-Pakistan \\ 3. Department of Chemistry, University of Turbat, Kech, Makuran-Pakistan \\ 4. Faculty of Water Resources Management, LUAWMS, Uthal Balochistan-Pakistan \\ *Corresponding author's email: iftekharbaloch@gmail.com \\ Citation \\ Abdul Hameed-Baloch, Iftekhar Ahmed Baloch, Hanif-ur-Rehman, Imtiaz Ahmed and Saeed Ahmed. A study of \\ poisonous plants of Balochistan, Pakistan. Pure and Applied Biology. http://dx.doi.org/10.19045/bspab.2017.600105

\begin{tabular}{llll}
\hline \hline Received: 28/01/2017 & Revised: 08/08/2017 & Accepted: 15/08/2017 & Online First: 16/08/2017 \\
\hline \hline
\end{tabular}

Poisonous plants growing in the different areas of Balochistan province were reviwed for their indigenous usage and chemical constituents. A total of 23 plant species (Acroptilon repens, Calotropis procera, Catharanthus roseus, Daphne mucronata, Datura innoxia, Datura stramonium, Eremostachys vicaryi, Euphorbia helioscopia, Heliotropium europaeum, Hyoscyamus insanus, Hyoscyamus niger, Iphiona aucheri, Melia azedarach, Melica persica, Nerium oleander, Phragmites karka, Sorghum helepense, Podophyllum emodi, Rhazya stricta, Solanum incanum, Solanum miniatum, Tephrosia apollinea and Xanthium strumarium) belonging to 12 different families (Apocynaceae, Asclepiadaceae, Astraceae, Boraginaceae, Euphorbiaceae, Lamiaceae, Meliaceae, Papilionaceae, Poaceae, Podophyllaceae, Solanaceae and Thymelaeaceae) were considered poisonous due to their toxic effects against livestock and human beings. These include one (1) tree, three (3) shrubs, eighteen (18) perennial herbs and one (1) annual herb. Most of them are found in southern regions of Balochistan province. Despite some harmful effects on human health, these plants are also considered as medicinally important and normally used in folk medicine. It is mostly because these poisonous plants in general are not harmful to human health but cause toxicity when consumed in large quantities. However, some of these dangerous poisonous plants may also cause serious hazards on human health even if consumed in small quantities.

Keywords: Balochistan; Folk medicine; Poisonous plants

Abbreviations: Balochi (Bl), Brahvi (Br), Pashto (Pash), Persian (Pers)

\section{Introduction}

Plants unlike animals are immobile and cannot escape their predators; therefore they have to produce a defensive mechanism which protects them from the predation. For this purpose, during the course of evolution, some plants turned into poisonous ones by producing secondary metabolites that are noxious for herbivorous animals. Unfortunately it is hard to define the poisonous plants, because a poisonous plant at the same time is also considered a beneficial one for the cure of particular ailments. According to Ahmed (2012) [1], a poisonous plant is defined as a plant whose particular part(s) when consumed in a certain amount causes some impaired functions or abnormality in the body of the subject. The poisonous activities of plants are the results of producing the secondary metabolites which include, tannin, alkaloids, terpenoids, phenols, saponins as well as some more complex compounds such as polyacetylenes. Like medicinal plants, these poisonous plants are also classified into 
different groups based on presence of certain chemicals such as alkaloids, glycosides, tannins, phenols and volatile oils [1]. The medicinal plants play an important role in everyday life of rural folks and from medieval time till today they use these plant or part(s) of plants for the cure of different ailments. However, some medicinal plants also possess lethal effects on human beings when consumed in large quantities. Therefore, a comprehensive survey of different plant species of Balochistan has been carried and the poisonous plants were screened out and enlisted in this paper.

\section{Methodology}

Natural flora of Balochistan province was surveyed and catalogued with the help of "Flora of Pakistan" [2]. During these surveys the rural folks of Balochistan were interviewed for local usage of different plants used for the cure of different ailments. The poisonous plants were screened out from this exhaustive floristic list. The local name(s) as informed by the local folks during the survey are also mentioned. Upon availability of information, these names are mentioned in local languages of Balochistan province that include, Balochi (Bal.), Brahui (Br.), Lasi, Pashto (Pash.) and Persian (Pers). Besides the uses of these poisonous plants mentioned in available scientific literature, the folk uses as informed by local inhabitants are also included. The gathered information was again reviewed with the help of available scientific literature and the phytochemical studies of these plants were documented.

The poisonous plants of Balochistan province are summarized below and categorized into alphabetical orders of families followed by species. The images of these poisonous plants alongwith their names are shown in figure 1 .

\section{Family: Apocynaceae}

1. Species: Catharanthus roseus (L.) G. Don English Name: Madagascar periwinkle or Rosy periwinkle

Local name: Sadabahar (Bal. Br.), Distribution in Balochistan: Ornamental plant of parks and gardens of southern Balochistan.

Habit: It is an evergreen subshrub or herbaceous plant growing $1 \mathrm{~m}$ tall.

\section{Local uses and chemical constituents:}

(1) Cultivated as an ornamental plant.

(2) All parts of C. roseus are highly toxic due to presence of more than 130 alkaloids which have been isolated from different parts. Although two important alkaloids (Vinblastine and Vincristine) are used in cancer treatment but they are present in very low concentrations [3].

\section{Species: Nerium oleander $\mathbf{L}$.}

English Name: Oleander

Local name: Jaur (Bal, Br) Gander, Ganderae (Pash.) and Kuran (Lasi).

Distribution in Balochistan: Shadi Kor, (Pasni), Hingol Kor, (Lasbela), Basol Kor, (Kalmat), Kech Kor, (Turbat), Bolan Pass, Shahrag, Lasbela and Zhob areas.

Habit: An erect evergreen shrub

\section{Local uses and chemical constituents:}

(1) Cultivated as an ornamental plant

(2) All parts of plant are highly toxic.

(3) The toxicity of plant is due to presence of two hazardous compounds i.e. oleandrin and oleandrigenin which are also known as cardiac glycosides and cause cardiac arrest if foliage and other parts of plant are ingested in higher quantity by livestock [4].

(4) Results of experiments conducted by Szbuiewicz et al [4] and Wasfi et al [5] showed that rodents and birds were insensitive to oleander cardiac glycosides; however dogs and humans were relatively sensitive to effects of cardiac glycosides.

(5) Although this plant is known for its higher toxicity but from 1985 through 2005 there were 847 human reported in United States who were exposed with the Narium toxicity and only three deaths were reported. [6].

(6) An incident was reported by Wasfi et al [5] of a person who consumed the aerial parts of plant for the cure of his diabetic problem. According to their findings the deceased person's blood indicated a total blood concentration of cardiac glycosides of approximately $20 \mu \mathrm{g} / \mathrm{L}$, which is well above the reported fatal level.

(7) When an individual consumes the foliage parts of oleander, within a few hours severe gastroenteritis, diarrhea, abdominal pain, sweating, and weakness are apparent. Cardiac 
irregularities are also common, often characterized by increased heart rate. However, a slower heart rate is often detected in the later stages.

\section{Species: Rhazya stricta Decne.}

Local name: Aeshark, Aizhwarg, Hishwarg, Hezhwar, Hishark, Eshark, Aishwarg (Bal.Br.)

Rangobul, Phalz, Urgalam, Urgalami, Hezhwarg or Hayanwarg (Pash.) Sehar (Lasi).

Distribution in Balochistan: Pab hills (Khuzdar), Bolan, Sharag, Basol, (Ormara), Nokbur, (Kolanch area, Gwadar), Lasbela, Loralai, Kharan, Quetta, Bolan, Loralai and Kohlu.

Habit: A stout erect evergreen shrub Local uses and chemical constituents:

(1) Clinically it has been proven that leaves extract of $R$. stricta showed significantly decreased total and ambulatory activities when administered in lab animals [7].

(2) The phytochemistry of $R$. stricta reveals that it contains over 100 alkaloids but the pharmacological activities are known for only a few of these compounds $[8,9]$.

(3) The cattle do not like this plant due to its toxic characteristics $[10,11]$.

\section{Family: Asclepiadaceae}

4. Species Calotropis procera subsp.

hamiltonii (Wight) Ali

English name: Apple of Sodom

Local name: Kurk, karag, Karagh (Bal.), Aragh (Br.) Karag (Lasi) Ispalmen (Pash.) Aak, Madar, Mundar (Lasi).

Distribution in Balochistan: Khuzdar, Wadh, Drakalo, Rustam Khan. Lasbela, Bolan and Sibi districts.

Habit: Erect shrub

\section{Local uses and chemical constituents:}

(1) Its milky latex is also used with other ingredients [12].

(2) The milky latex is nuisance when it comes in contact with skin mucous membrane and said to cause blindness [2].

(3) Although C. procera is a poisonous plant

but it is used for snake and insects bite. The milky latex is applied externally on affected area to reduce the poison's effect. It is also used as a purgative and said to be specific for Guinea worms [10].
(4) The flowers of the plant are dried to make a tablet from its powder which is used for constipation [10].

(5) Leaves of plant are slightly roasted and then squeezed to obtain a juice which is used for ear diseases. The ashes of leaves are used as antiseptic drug [11].

(6) The warmed leaves are used as a poultice.

(7) The flowers of this plant are put in oil and applied to wounds to cure them.

(8) Its latex from the stem was used to empoison the hunting arrows during the ancient time.

\section{Family: Astraceae}

5. Species: Acroptilon repens (L.) DC.

Englih name: Russian knapweed

Local name: Talkha, Talkha Kao, Tulkha (B1, Br), Kuragh (Pash.).

Distribution in Balochistan: Kalat, Mangocher, Nimargh, Harboi, Nichara Wad (Khuzdar District) and Loralai.

Habit: Perennial weed. Creeping roots usually dark brown or black, with scaly adventitious buds.

\section{Local uses and chemical constituents:}

(1) The whole plant is boiled in water and syrup is used for blood purification.

(2) In Loralai area the plant is used for the cure of wounds of sheep.

(3)The plant is very poisonous to horses, causing neurological symptoms. Because of its sour taste, grazing animals usually avoid it, and consequently it tends to spread more than edible plants in the field.

\section{Species: Iphiona aucheri}

Local name: Kollmir, Kolmurag (B1. Br.)

Distribution in Balochistan: Makuran, Kharan, Lasbela and Khuzdar

Habit: Perennial herb, Chamaephyte.

Local uses and chemical constituents:

(1) It is a highly poisonous plant.

(2) Iphiona aucheri is responsible for poisoning of racing camels in U.A.E. Two diterpene glycosides, atractyloside and carboxyatractyloside have been identified as the toxic principle of the plant [13].

(3) Because of its toxicity, I. aucheri is avoided by grazing animals of Balochistan and remains evergreen all year around. It is one of the reasons that in Balochi folklore this plant's 
name is used metaphorically for a person who is always jubilant and carefree [12].

\section{Species: Xanthium strumarium L.}

English Name: Rough cocklebur

Local name: Lichok wal (Bl.)

\section{Distribution in Balochistan:}

Lasbella

Habit: Herb, annual, $20-120 \mathrm{~cm}$ with a tap root, spreading by seeds only.

Local uses and chemical constituents:

(1) Xanthium strumarium L. is widely used in traditional folk medicinal systems and the whole plant, particularly the leaves are used by hakims as blood purifier and in scabies. The phytochemical investigations of leaves revealed that foliage parts of plant contained various bioactive molecules, amino acid composition and minerals. Plant is rich in potassium and contains flavonoids, catechol, alkaloids, cardenoloids and many free amino acids [14].

(2) In Ayurveda (The Hindu folk medicinal tradition) it is called 'Shankeshwara'and 'Arishta', and is considered anthelmintic, antipyretic, diuretic, laxative, alexiteric, tonic, digestive and appetizer. It improves voice and complexion and is used in epilepsy, leucoderma and as antidote for insect bite [15].

(3) Fruits are plentiful in vitamin $\mathrm{C}$ and are considered to be cooling and demulcent in indigenous system of medicine.

(4) Ashes of aerial parts of plant are applied to sores on lips and mouth.

(5) Roots are bitter and used in cancer, scrofula, boils, and ulcers.

(6) Leaves are used in herpes and malaria.

(7) Seeds are used for treatment of eye diseases, headache, piles and cancerous wounds.

(8) Flowers and fruits are used to prepare a drink while seedlings and leaves are used as vegetable [16].

(9) The seedlings and seeds of $X$. strumarium contain the glycoside carboxyatractyloside and can be poisonous to livestock, including cattle, horses and pigs. It is reported that Carboxyatractyloside poisoning causes multiple organ dysfunctions and can be fatal. The symptoms include coagulation abnormalities, hyponatraemia, marked hypoglycaemia, hepatic and renal failures are signs of a poor prognosis. Unfortunately, there is no remedy for it and supportive treatment is the mainstay of treatment [17]. The plant parts are also used for medicinal purposes such as treatment of cancer, tuberculosis, wounds, headache, malaria, rheumatism and show antibacterial activity against Staphylococcus aureus species [18].

(10) The mature plant is reported as harmless; although toxicity has been reported in livestock that ingested mature plants with burs despite the general belief that ingestion of burs should be limited by mechanical injury during mastication [18].

(11) There are a few case reports about $X$. strumarium poisoning in human. If ingested, the symptoms include acute onset of abdominal pain, nausea and vomiting, drowsiness, palpitations, sweating and dyspnea. Convulsions followed by loss of consciousness and death have also been reported [19].

\section{Family: Boraginaceae}

8. Species: Heliotropium europaeum var. lasiocarpum (F \& M.) Kazmi.

English name: European heliotrope

Local name: Poput, Kapothchum (B1.), Sago (Pash.)

Distribution in Balochistan: Lasbela, Makuran.

Habit: Annual, $50 \mathrm{~cm}$ or more tall, branched.

Local uses and chemical constituents:

Heliotropium europaeum contains pyrrolizidine alkaloid which is poisonous [20].

Family: Euphorbiaceae

9. Species: Euphorbia helioscopia L.

English name: Wart spurge, Umbrella milkweed

Local name: Zahrichk, Gurbagoond, Shohrbulok (Bl.), Rechask (Br.)

Distribution in Balochistan: Northern and Central Balochistan.

Habit: An erect bright green fleshy annual herb up to $50 \mathrm{~cm}$ tall, but more commonly $10-30 \mathrm{~cm}$ tall.

\section{Local uses and chemical constituents:}

(1) It is a highly poisonous plant [20].

(2) The active ingredients are used in pharmaceutical industry [20].

(3) The plant contains the jatrophone-type diterpenoids euphoheliosnoid A, B, C [21] and 
D [22] and other toxic diterpenes such as euphoscopins, epieuphoscopins euphornins, cuphohelioscopins and euphohelionone [23].

(4) Several biologically important chemical compounds have also been isolated from the aerial parts of this plant including four esters of 12-deoxyphorbol (12-Deoxyphorbol-13phenylacetale-20-acetate, 12-deoxyphorbol13-dodec-dienoate-20-acetate,

deoxyphorbol-13-[2-methyl-cis-2-butenoate]-

20-acetate and 12-deoxyphorbol-13-[2-methylcis-2-butenoate]). These substances are the major causes of skin irritantation when latex of this plant comes in contact with victim's skin. [24]. Similarly m-Hydroxyphenylglycine and 3,5-dihydroxyphenylglycine are two amino acids that can be isolated from the latex of $E$. helioscopia [25].

(5) The detailed phytochemistry of this poisonous plant is as follows: Helioscopinin A (1,6-(S)-hexahydroxydiphenoyl-2,4-(S)-

dehydrohexahydroxydiphenoyl-3-O-galloyl- $\beta$ D-glucose), helioscopinin B (1,6-(S)-

hexahydroxydiphenoyl-3-O-galloyl- $\beta$-D-

glucose), helioscopin A (1,6-(S)hexahydroxydiphenoyl-2,4-(R)-

elaeocarpusinoyl-3-O-galloyl- $\beta$-D-glucose) and helioscopin B (1,3,6-tri-O-galloyl-2,4-(R)elaeocarpusinoyl- $\beta$-D-glucose) can be found together with the 8 other tannins corilagin, punicafolin, geraniin, elaeocarpusin, furosin, terchebin, mallotusinin and carpinusin [26].

Helioscopinin-A shows anti-allergic and antiasthmatic activities in guinea pigs. It is suggested that this compound exerts its activities through antagonism on leukotriene D4-induced responses [27].

\section{Family: Lamiaceae}

10. Species: Eremostachys vicaryi Benth.

English name: Eremostachys

Local name: Bishhaf, Bishkhaf, Gurganna, Khalatri, Rewand-chin. (B1. Br.)

Distribution in Balochistan:

Northern Balochistan

Habit: Root thick, vertical. Stems solitary or few, 40-90 cm, simple or branched at Inflorescence.

\section{Local uses and chemical constituents:}

(1) Stewart, J. L. (1869) [28] reported that the plant was used for poisoning the fish near Peshawar.

(2) The phytochemistry of this plant revealed the presence of

(a) Vicarin, an isoflavone, which had been isolated from the ethyl acetate-soluble fraction of the ethanolic extract of Eremostachys vicaryi,

(b) Soforanarin B

(c) luteolin 7-O- $\beta$-D-glucopyranoside and

(d) hamighriprasin [29].

Family: Meliaceae

11. Species: Melia azedarach $\mathrm{L}$.

English name: White cedar, Chinaberry tree

Local name: Bakaur, Bakain, Dhrek (Bl. Br.), Bakain (Pash.), Senjid-i-talkh (Persian)

Distribution in Balochistan: Kalat, Quetta, Pishin, Nasirabad and Makuran. It is a fast growing tree of the plains and foot-hills, cultivated along road-sides and in villages.

Habit: Tree, up to $12 \mathrm{~m}$ tall.

Local uses and chemical constituents:

(1) The oil extracted from the seeds is used as hair oil.

(2) The leaves are so bitter that even locusts leave them [12].

(3) The fruit is used by goats and sheep and the stony endocarps are used as beads.

(4) Fruits are poisonous to humans if eaten in large quantity. The toxins are neurotoxins and unidentified resins. The first symptom of poisoning appears a few hours after intake. The symptoms of poisoning are loss of appetite, vomiting, constipation or diarrhea, bloody faeces, stomach pain, pulmonary congestion, cardiac arrest, rigidity, lack of coordination and general weakness. Death may take place after about 24 hours [20].

(5) Leaves are used as a natural insecticide to keep with stored food, but must not be eaten, as they are highly toxic [20].

Family: Poaceae

13. Species: Melica persica Kunth, Rev. Gram.

Local name: Lewanai butae (Pash.)

Distribution in Balochistan: Ziarat in the Juniper tracts, common among bushes. 
Habit: Rhizomatous perennial forming clumps up to $45 \mathrm{~cm}$ across; culms $15-50 \mathrm{~cm}$ high, erect or ascending.

Local uses: The use of this grass as fodder is uncertain because Stewart and Santapau reported that it is, or may be, poisonous to stock while Helen Crookshank noted that it is heavily grazed [2].

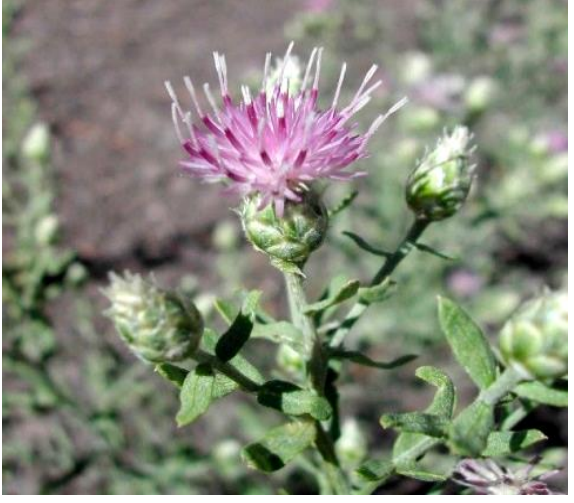

Acroptilon repens (L.) DC.

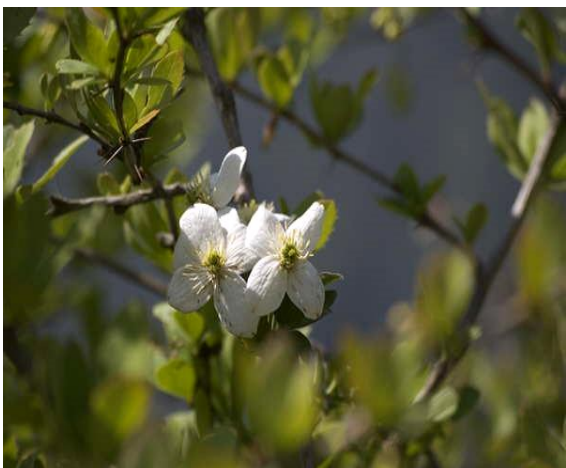

Daphne mucronata Royle.

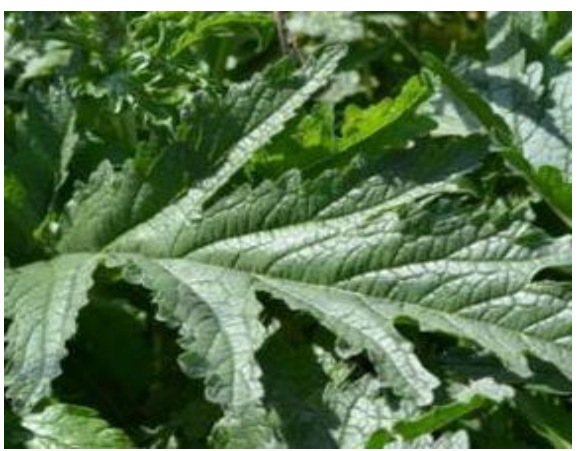

Eremostachys vicaryi Benth.

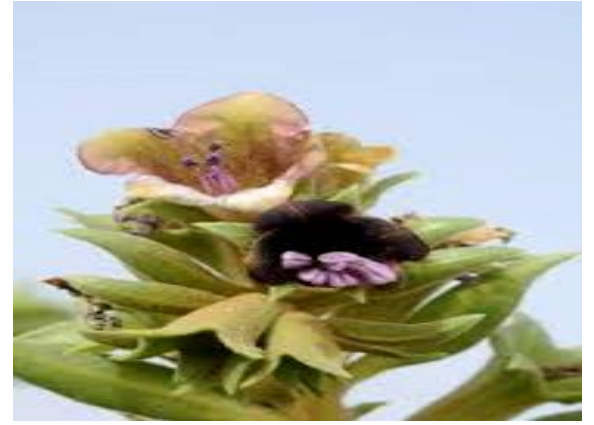

Hyoscyamus insanus Stocks.

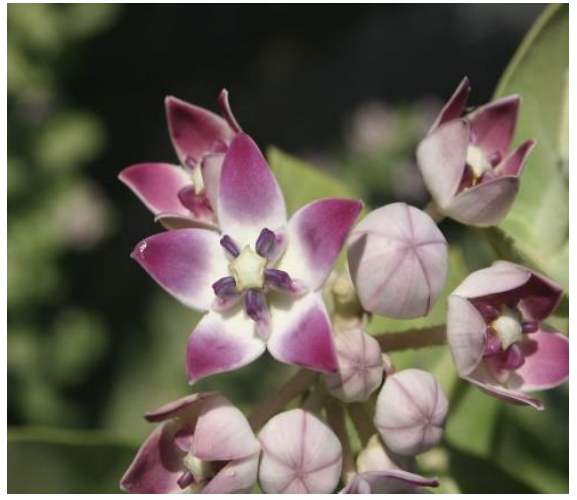

Calotropis procera ssp. hamiltonii (Wight) Ali

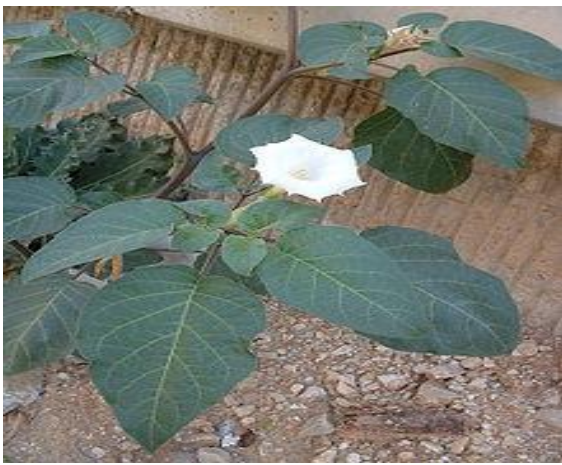

Datura innoxia Miller

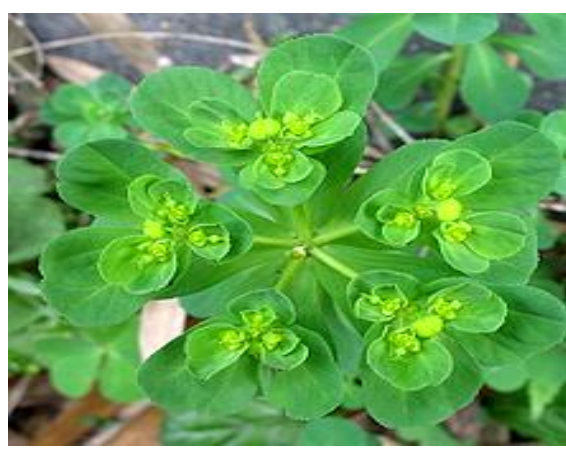

Euphorbia helioscopia L.

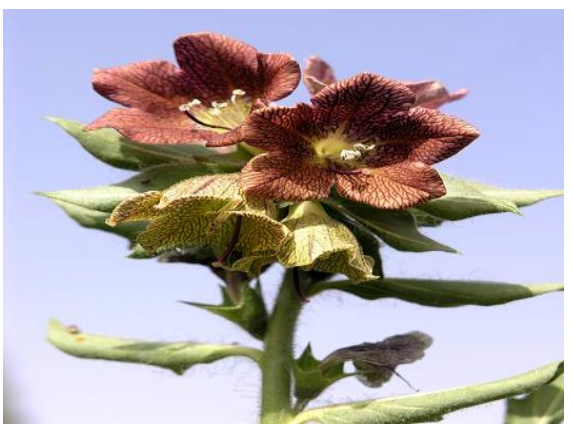

Hyoscyamus niger L.

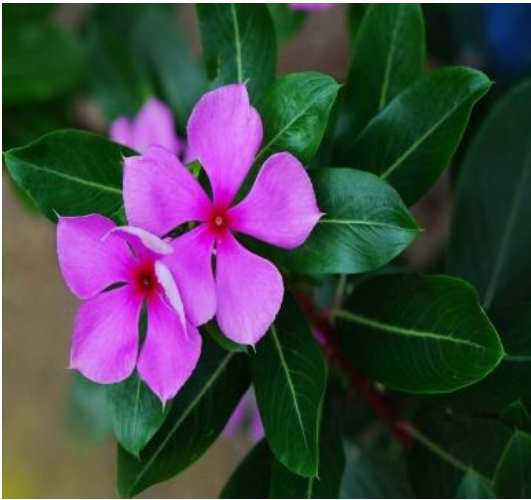

Catharanthus roseus (L.) G. Don

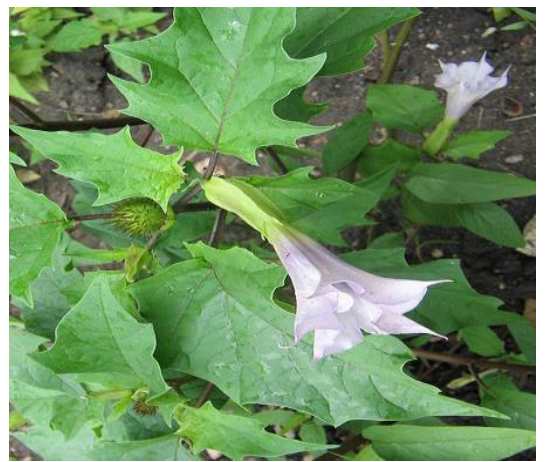

Datura stramonium L.

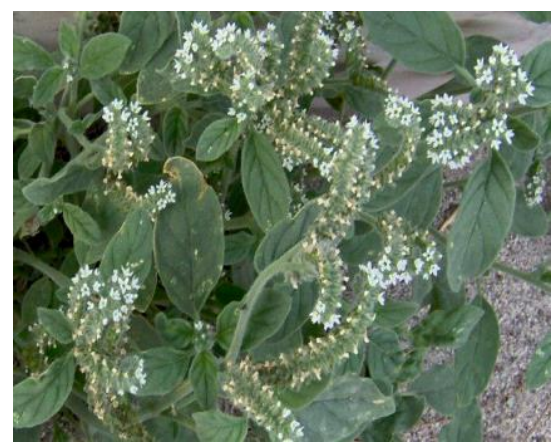

Heliotropium europaeum var. lasiocarpum (F.\&M.) Kazmi.

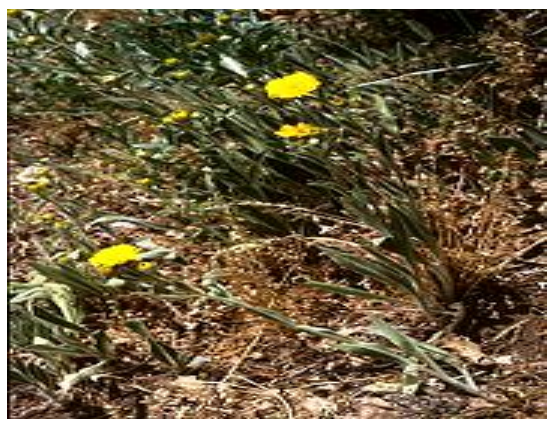

Iphiona aucheri 


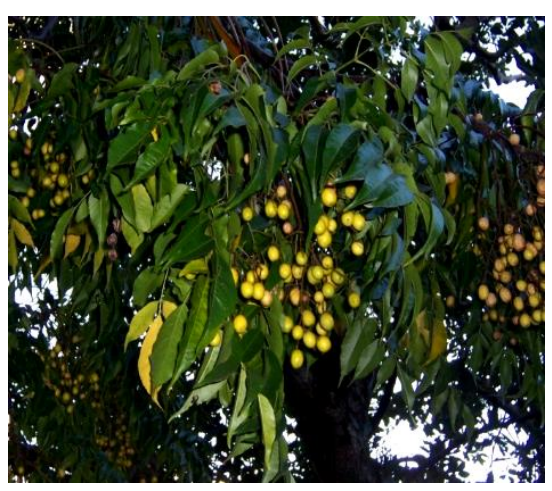

Melia azedarach $\mathrm{L}$.

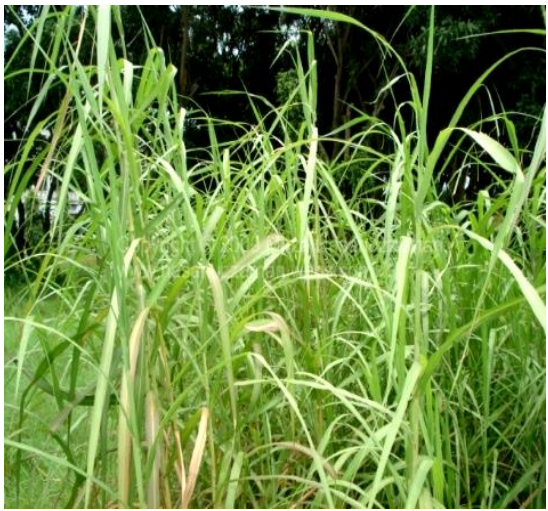

Phragmites karka (Retz.) Trin. ex

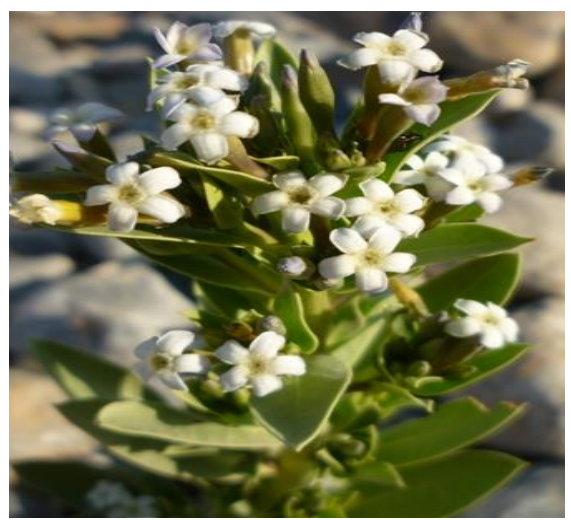

Rhazya stricta Decne.

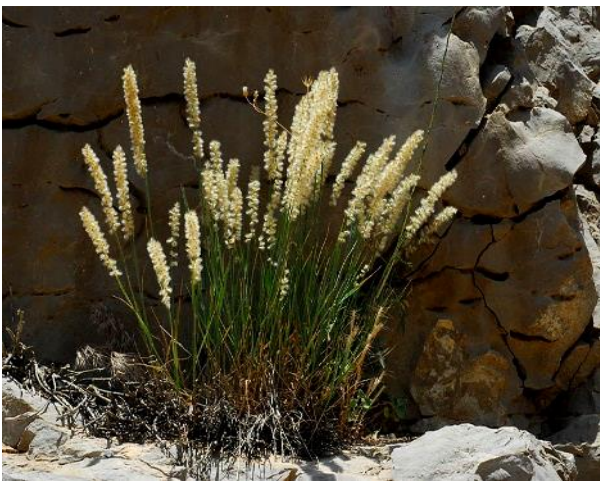

Melica persica Kunth, Rev. Gram.

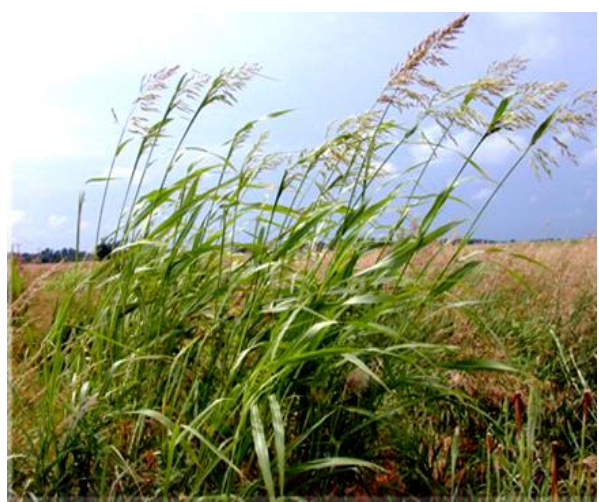

Sorghum helepense (L.) Pers.

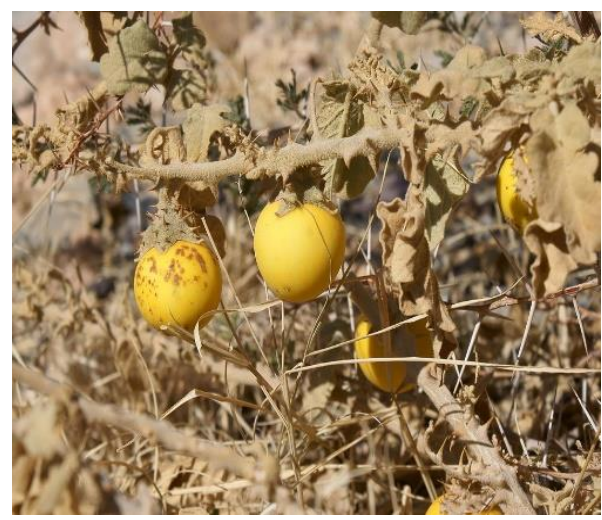

Solanum incanum

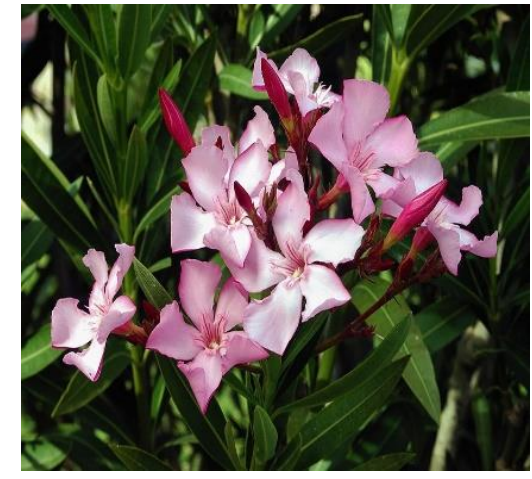

Nerium oleander L.

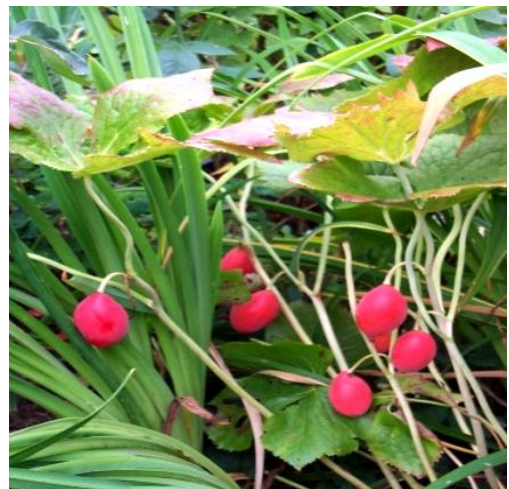

Podophyllum emodi Wall. ex

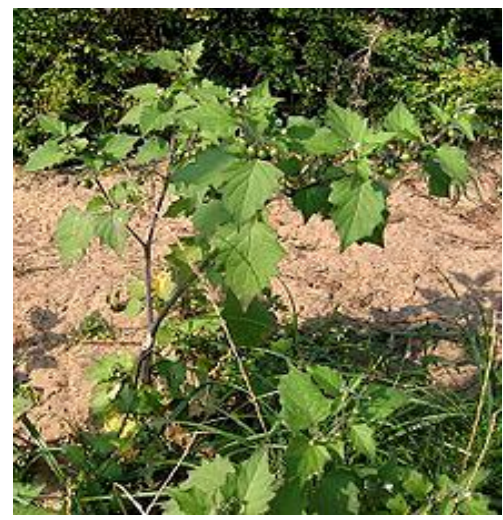

Solanum miniatum L.

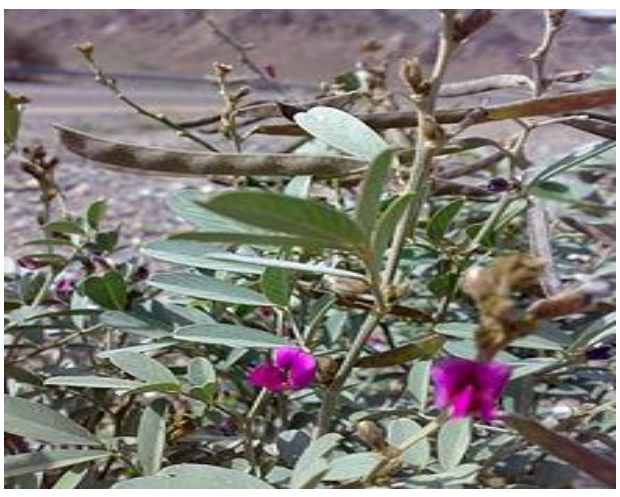

Tephrosia apollinea (Delile) Liuk

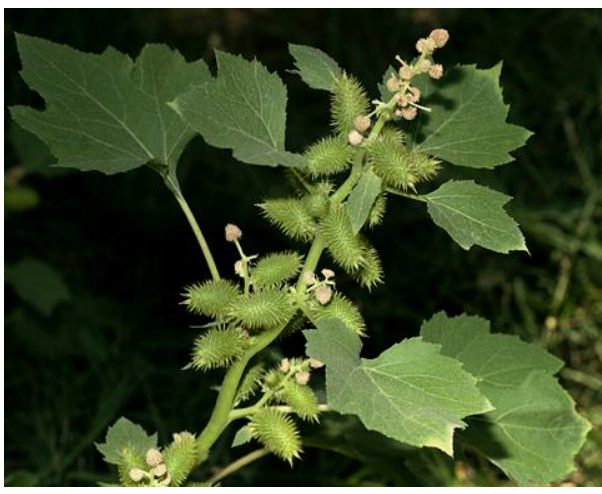

Xanthium strumarium L.

Figure 1. Poisonous plants found in Balochistan 
14. Species: Phragmites karka (Retz.) Trin. ex Steud.

English name: Tall Reed

Local name: Nal, Drogg, Masolk, Narrh, Nal

(Bl. Br.), Narrh (Lasi) Drumbi, Nar, Nalu.

Distribution in Balochistan: Lasbela District.

Habit: Perennial reed, with creeping rhizomes. Culms erect, up to $10 \mathrm{~m}$ high.

Local uses:

(1) Qasim et al. 2010 [31] reported this grass is used as a fodder in Lasbela region but it is far too coarse for fodder.

(2) It is said to be poisonous to cattle."

15. Species: Sorghum helepense (L.) Pers.

English name: Johnson grass

Local name: Gomaaz, Baran Sohro (B1.) Baru,

Baran, Targhar (Pash.), Jowari (Lasi)

Distribution in Balochistan: It is usually found in fields, roadsides and waste places.

Distributed in upper Zhob, Shahrugh and Kohlu area (Sibi Division) Loralai area, Kachhi area, Makuran and Lasbela Districts [12].

Habit: Rhizomatous perennial; culms simple or branched, $0.5-3 \mathrm{~m}$ high or more, slender to rather stout. Leaf-blades $20-90 \mathrm{~cm}$ long, 0.5-4 cm wide.

\section{Local uses and chemical constituents:}

(1) Plant tissues contain hydrocyanic acid which show a positive danger to livestock [32].

(2) Under certain conditions $S$. helepense is poisonous to livestock.

Family: Podophyllaceae

16. Species: Podophyllum emodi Wall. ex Royle.

English name: Indian Podophyllum, Himalayan May Apple

Local name: Bankarki, Papra, Banwagan (Pash.)

\section{Distribution in Balochistan}

Northern Balochistan

Habit: Perennial herbs, 15-30 (-45) cm. tall, erect, smooth, glabrous.

Local uses and chemical constituents:

(1) Fruits are edible and rootstock produce podophyllol, a sticky resin, quarcetin and podophyllo-toxin of medicinal importance [2]. (2) The plant is poisonous. The rhizome of the plant contains a resin, which can be processed to extract podophyllotoxin, or podophyllin, a neurotoxin [20].
(3) The antitumor effect of $P$. hexandrum was observed in experimental animals carrying solid tumours developed by transplanting Ehrlich Aascites Tumour (EAT). Subtoxic well-tolerated sequential doses of aqueous extract of $P$. hexandrum (a daily dose of 34.5 $\mathrm{mg} / \mathrm{kg}$ b.w. for 15 days) enhanced tumourdoubling time (TDT) from $1.94+/-0.26$ days to $19.1+/-2.5$ days. The results of this experiment revealed that there was no synonyme ergism revealed between radiation and $P$. hexandrum, though both independently manifested antitumor effects [33].

(4) The rhizome of $P$. hexandrum contains several lignans, which possess antitumor activity. Podphyllotoxin is the most active cytotoxic natural product. It is used as starting compound for the synonym thesis of anticancer drug etoposide and teniposide. Podophyllotoxin acts as an inhibitor of microtubule assembly. These drugs are used for lung cancer, testicular cancer, neuroblastoma, hepatoma and other tumors. Availability of podophyllotoxin from plants has its limitations because of its intense collection from nature and lack of organized cultivation [34].

Family: Solanaceae.

\section{Species: Datura innoxia Miller}

English name: Recurved thorn-apple

Local name: Dathura (Bal. Br.)

Distribution in Balochistan: Lasbela District. Usually grows on roadsides and weedy places, from sea level to $1524 \mathrm{~m}$.

Habit: Plant up to $130 \mathrm{~cm}$ tall, branched, dense pubescent-villous.

\section{Local uses and chemical constituents:}

(1) Extract of leaves is helpful in toothache, headache and epilepsy.

(2) Leaves extract effect the nervous system, overdose may induce vomiting, coma and even death.

(3) Seeds are antipyretic, anti-rabies and narcotic.

(4) The poisonous seeds are intoxicating and are also used as a cure for hydrophobia.

(5) The plant contains two main toxic alkaloids, atropine and scopolamine.

(6) To investigate the effect of intoxication due to consumption of plant materials, urine and plasma samples of the seven patients, as well as 
a sample of cooked vegetables, were analyzed with gas chromatography-mass spectrometry by Papoutsis et al. (2010) [35]. The urine and plasma sample confirmed the presence of atropine and scopolamine. The urine samples of all patients contained atropine in concentrations between 67.1 and $691.7 \mathrm{ng} / \mathrm{mL}$, while urine concentrations of scopolamine ranged from 32.4 to $186.4 \mathrm{ng} / \mathrm{mL}$. The concentrations of atropine and scopolamine in the cooked vegetables were found to be 0.8 and $1.2 \mu \mathrm{g} / \mathrm{g}$, respectively. The patients who by mistake or deliberately consumed the plant materials required mechanical ventilation. The results of this experiment revealed the risks of using of $D$. innoxia for medicinal purposes.

\section{Species: Datura stramonium L.}

English name: Jimson weed or Devil's snare

Local name: Dathura, Sinah-Azghi (Bal. Br.) Shinah (Pash.)

\section{Distribution in Balochistan:}

Northern Balochistan

Habit: Plant $60-120 \mathrm{~cm}$ or even taller, branched, pubescent; the branches are often purplish.

\section{Local uses and chemical constituents:}

(1) The plant has a very strong smell and is extremely poisonous and contains alkaloids as hyoscyamine and scopolamine, which are classified as deliriants, or anticholinergics, which have a powerful narcotic effect. There is a high risk of fatal overdose amongst uninformed users [36].

(2) The amount of toxins varies and depends on its age, place where it is growing, and the local weather conditions [36].

(3) Datura intoxication typically produces hallucination; hyperthermia; tachycardia; strange behavior; and severe mydriasis with consequential painful photophobia that can last for several days and pronounced memory loss [37].

(4) The Datura seed contains about $0.1 \mathrm{mg}$ of atropine, and the fatal dose for adult humans is $>10 \mathrm{mg}$ atropine or $>2-4 \mathrm{mg}$ scopolamine [38].

(5) Although, livestock do not prefer this weed, but may be poisoned by eating very small plants or some leaves when mixed with regular fodder [32].
(6) In Indian traditional medicine the flowers of plant have long been used as an extremely effective treatment for asthma symptoms. The active anti-asthmatic agent is atropine, which causes paralysis of the pulmonary branches of the lungs, eliminating the spasms that cause the asthma attacks.

(7) The plant parts are used in fevers, for worms, skin diseases, boils and indigestion [2].

(8) Seeds possesse higher potential of dormancy when remained in soil seed bank.

19. Species: Hyoscyamus insanus Stocks.

Local name: Kakeink, Koh-e-Bang, Kohbanan (B1.), Kohbanan (Br.) Ghurso nohai, Narhai (Pash).

\section{Distribution in Balochistan:}

Northern Balochistan

Habit: Perennial up to $70 \mathrm{~cm}$ tall, branched.

\section{Local uses and chemical constituents:}

(1) Burkill (1909) [12] mentioned that local people of Balochistan smoked the leaves of this plant but it was not proved by any other study.

(2) This species is also used for the medicinal purposes.

(3) The biochemical analysis of this plant demonstrated that it contains three alkaloids i.e. Hyoscyamine (atropine), hyoscine and apoatropin. More than $70 \%$ of the total alkaloids were hyoscyamine. Regarding this high percentage of hyoscyamin, this species could potentially be used for large-scale production [39].

20. Species: Hyoscyamus niger $\mathrm{L}$.

English name: Black henbane or Stinking nightshade.

Local name: Kohi bang (Bl. Br.)

Disrtibution in Balochistan:

Northern Balochistan

Habit: Plants annual or biennial, up to $1.5 \mathrm{~m}$ tall, pubescent to hairy.

\section{Local uses and chemical constituents:}

(1) This is a very toxic plant. Hyoscyamine, scopolamine, and other tropane alkaloids have been found in the foliage and seeds of the plant.

(2) The effects of poison include

hallucinations, dilated pupils, restlessness, and flushed skin. Less common symptoms are tachycardia, convulsions, vomiting, hypertension, hyperpyrexia and ataxia [20]. 
(3) In low doses henbane can be toxic, even fatal, to animals.

\section{Species: Solanum incanum L.}

English name: Bitter apple and Bitterball

Local name: Bătāg, Bhaer (Bal)

Habit: Shrub up to $120 \mathrm{~cm}$ tall.

Distribution in Balochistan: Common in the plains and the lower hills up to $1400 \mathrm{~m}$.

Local uses and chemical constituents:

(1) The plant parts used in folk medicine, as a remedy for toothache, sore throats and in chest complaints [2].

(2) Local people also use the fruits of $S$. incanum for the treatment of cutaneous mycotic infections and other pathological conditions.

(3) It is reported to contain solanine and related glycoalkaloids. The crystals of this compound are effective inhibitors of the growth of grampositive and gram-negative bacteria, yeasts, dermatophytes, and some pathogens of agricultural [40].

(4) The toxicity of unripe fruits of $S$. incanum (L.) in goats was observed by Thaiyah et al. (2010) [41]. Dried unripe fruits of $S$. incanum (L.) were orally fed to goats at a dose rate of 0 (group1), 0.75 (group 2), 1.5 (group 3) and 2.25 (group 4) $\mathrm{g} / \mathrm{kg} /$ day for 9 weeks. The four treated groups of goats showed bloat, colic, coughing and shivering while one goat had additional signs of depression, staggering gait and continuous bleating before death. The results obtained from these experiments indicated that unripe fruits of $S$. incanum (L.) are toxic to goats and allowing animals to graze on this plant could be deleterious to their health.

\section{Species Solanum miniatum $\mathbf{L}$.}

Local name: Tol angur, Mukko (Bl. Br.), Angun, Kamuri, Mako, Karezgi (Pash), Tajrizi (Pers).

\section{Disrtibution in Balochistan:}

Northern and northern Balochistan

Habit: Annual, 15-60 cm tall [2].

Local uses and chemical constituents:

(1) The fruits (berries) are bitter, pungent, heating, laxative, aphrodisiac, tonic, diuretic, appetizer and useful in diseases of the heart, leucoderma, fever, diarrhoea, ophthalmia, hydrophobia.

(2) In Loralai District the ripened fruits are eaten locally [12].
(3) The plant has long been regarded as poisonous, and several incidents of toxicity were reported in United State, particularly green berries which contained carcinogenic compounds [32].

Family: Thymelaeaceae

23. Species: Daphne mucronata Royle. Local name: Mantrah, Pipal (Bl. Br.) Disrtibution in Balochistan:

Northern Balochistan

Habit: A xerophytic Shrub up to $2.5 \mathrm{~m}$ tall. Local uses and chemical constituents:

(1) The leaves are poisonous but are endured by goats.

(2) The bark is used in diseases of bone and for washing hair.

(3) The wood used for making charcoal for heating and cooking.

(4) The fruit can be eaten and is used as a dye for leather [2].

(5) The phytochemistry of plant demonstrated that the alcohol extracts of Daphne mucronata to a group of breast tumor bearing rats, for more than 20 consecutive days, reduced significantly the diameter of tumor or eliminated them totally if the treatment continued for a longer time [42].

(6) Several novel chemical compounds have been isolated from different parts of this plant, one of them is Gnidilatimonoein, a diterpene ester, which was isolated from the leaves with potent anti-tumoral and anti-metastastic activities. To prove the effect of leaf extracts on tumoral cells such as Promyeloblastic (KG1), promyelocytic (NB4) and promonocytic (U937) cells were cultured in various concentrations of the drug $(0.5-3.0 \mu \mathrm{M})$ for 3 days. The results showed that the drug inhibited growth and proliferation of KG1, NB4 and U937 cells with IC50 values of $1.5,1.5$ and 1.0 $\mu \mathrm{M}$, respectively, after $72 \mathrm{~h}$ of treatment. Similarly the Cell viability was also decreased by 18,20 and $23 \%$, respectively, after $72 \mathrm{~h}$ treatment with the drug. From these promising results it was concluded that the new compound is an effective chemotherapeutic agent acting through induction of differentiation and apoptosis [43].

(7) Similarly plant extract also showed a decreasing effect on the size of breast 
adenocarcinoma in rats. Because it boosted monocytes TNF- $\alpha$ releasing, which potentially inhibited Leukemia cell line [44].

\section{Conclusion and recommendations}

From ancient times till today, the local folks of Balochistan are dependent upon the medicinal plants for the cure of different ailments. Although it is true that herbal sources may have medicinal value and have shown promising results for the cure of different minor ailments. Unfortunately many of the important herbal remedies also possess hazardous compounds which show negative impacts when consumed in large quantities. On the other hand the ignorant people, believe that things that are "natural" are safer to use compared with allopathic drugs. It is clear from the above mentioned list that some of the most deadly poisons are screened out from these plants but the local folks are still using these plant parts. Similarly, during these surveys a stubborn misconception came to our knowledge that the local folks of Balochistan believe that if a plant bitter, it has the beneficial effects for the cure of diabetes. In conclusion it is highly recommended that before taking any medicinal plant as herbal remedy, people should know the known health hazard risks associated with these medicinal plants.

\section{Authors' contributions}

Conceived and designed the paper: AH Baloch, IA Baloch, HU Rehman, I Ahmed \& S Ahmed, Wrote the paper: AH Baloch \& IA Baloch.

\section{Acknowledegement}

We are thankful to the anonymous reviewers for their helpful suggestions which enabled us to present the refined version of this review article.

\section{References}

1. Ahmed S (2012) A study of poisonous plants of Islamabad area, Pakistan. Pak. $j$. sci. ind. Res. Ser. B: boil. Sci. 55(3): 129137.

2. Ali SI \& M Qaiser (Eds.). 1993-2015. Flora of Pakistan, Karachi.

3. Aslam J, Khan SH, Siddiqui ZH, Fatima Z, Maqsood M, Bhat MA, Nasim SA, Ilah A, Ahmad IZ, Khan SA, Mujib A \& Sharma MP (2010) Catharanthus roseus (L.) G. Don. An important drug: its applications and production. Pharmacie Globale (IJCP) 4 (12): 1-16.

4. Szabuniewicz M, Schwartz WL, McCrady JD, et al. (1972). Experimental oleander poisoning and treatment. Southwestern Vet. 25 (2): 105-114.

5. Wasfi IA. Zorob O, Al Katheeri, Nawal A. Al Awadhi \& Anwar M. (2008). A fatal case of oleandrin poisoning. Forensic Science International 179 (2-3): 220-225

6. Watson, William A., et al. (2003) 2002 Annual Report of the American Association of Poison Control Centers Toxic Exposure Surveillance System. American Journal of Emergency Medicine 21 (5): 353-421.

7. Ali BH, Bashir AK \& Tanira MOM (1999). The Effect of Rhazya stricta Decne, a Traditional Medicinal Plant, on Spontaneous and Drug-Induced Alterations in Activity of Rats. Pharmacology Biochemistry and Behavior. 64(3): 455459.

8. Gilani, SA, Kikuchi A, Shinwari ZK, Khattak ZI \& Watanabe KN (2007). Phytochemical, pharmacological and ethnobotanical studies of Rhazya stricta Decne. Phytother Res. 21(4): 301-307.

9. Ahmad M., Muhammed S, Jahan N, Jan, SU \& Qureshi, ZUR. (2014). Anti-dermatitis, anxiolytic and analgesic effects of Rhazya stricta from Balochistan. Pakistan journal of pharmaceutical sciences, 27(3).

10. Tareen RB, Bibi T, Khan MA., Ahmed M \& Zafar M (2010). Indigenous knowledge of folk medicine by the women of Kalat and Khuzdar regions of Balochistan Pakistan. Pak. J. Bot., 42(3): 1465-1485.

11. Qureshi R. (2012) Medicinal Flora of Hingol National Park Baluchistan, Pakistan. Pak. J. Bot. 44(2): 725-732.

12. Burkill, IH (1909). A Working List of the Flowering Plants of Baluchistan. Superintendent Government Printing: Calcutta. p. 136.

13. Roeder E, Bourauel T, Meier U \& Wiedenfeld H (1994). Iphiona aucheri. Phytochemistry. 37(2): 353-355.

14. Bhogaonkar PY \& Ahmad SA (2012). Pharmacognostic studies on Xanthium strumarium L. a folk Unani medicinal 
herb. Bioscience Discovery, 3(1): pp. 101106.

15. Agharkar SP (1991). Medicinal Plants of Bombay Presidency. FBI Science Publication, Jodhpur, pp.230.

16. Jain SK (1991). Contribution to Ethnobotany of India. Scientific Publication, Jodhpur.

17. Martin T, Stair EL \& Dawson L (1986). Cocklebur poisoning in cattle. J. Am. Vet. Med. Assoc. 189: pp. 562-563.

18. Saidi H \& Mofidi M (2009). Toxic effect of Xanthium strumarium as an herbal medicine preparation. EXCLI Journal 8: 115-117.

19. Yokoe H, Yoshida $M$ \& Shishido $K$ (2008). Total synthesis of (-)-xanthatin. Tetrahedron Lett. 49: 3504-3506.

20. https://en.wikipedia.org/wiki/ (Accessed June 25th 2013)

21. Zhang W \& Yue-Wei G (2006). Chemical Studies on the Constituents of the Chinese Medicinal Herb Euphorbia helioscopia L. Chemical and Pharmaceutical Bulletin. 54(7): 1037-1039.

22. Zhang W \& Yue-Wei G (2005). Three

23. New Jatrophone-Type Diterpenoids from Euphorbia helioscopia. Planta Med., 71(3): 283-286.

24. Yamamura S, Shizuri Y, Kosemura S, Ohtsuka J, Tayama T, Ohba S, Ito M, Saito Y \& Terada Y (1989). Diterpenes from Euphorbia helioscopia. Phytochemistry. 28(12): 3421-3436.

25. Schmidt, R.J., and Evans, F.J. (1980) Skin irritants of the sun spurge (Euphorbia helioscopia L). Contact Dermatitis. 6(3): 204-210.

26. Müller P \& Schütte HR. (1968). mHydroxyphenylglycine and 3,5dihydroxyphenylglycine, 2 new amino acids from the latex of Euphorbia helioscopia L. Z Naturforsch B. 23(5): 659-663.

27. Lee SH, Tanaka T, Nonaka G \& Nishioka I. (1990) Tannins and related compounds. $\mathrm{XCV}$. Isolation and characterization of helioscopinins and helioscopins, four new hydrolyzable tannins from Euphorbia helioscopia L. Chemical and
Pharmaceutical Bulletin. 38(6): pp. 15181523.

28. Stewart JL (1869) Punjab Plants. 168.

29. Imran M, Mehmood R, Mughal UR, Ali B \& Malik A. (2012) Vicarin, a new isoflavone from Eremostachys vicaryi. J. Asian Nat. Prod. Res. 14(3): 293-296.

30. Hagir, B., Suliman, I.A., and Wasfi, S.E.I., (1982) The toxic effects of Tephrosia apollinea on goats. Adam Journal of Comparative Pathology. 92(2): 309-315.

31. Qasim M, Gulzar S, Shinwari ZK, Aziz I, Khan MA (2010). Traditional Ethnobotanical Uses of Halophytes from Hub, Balochistan. Pak. J. Bot., 42(3): 1543-1551.

32. Anonymous (1962) Nebraska Weeds. Weed and Seed Division, Department of Agriculture and Inspection. State of Nebraska. Bulletin No. 101-R.

33. Giri A \& Lakshmi NM (2000). Production of podophyllotoxin from Podophyllum hexandrum: a potential natural product for clinically useful anticancer drugs. Cytotechnology. 34(1-2): 17-26.

34. Goel HC, Prasad J, Sharma A \& Singh B (1998). Antitumour and radioprotective action of Podophyllum hexandrum. Indian J Exp Biol. 36(6): 583-587.

35. Papoutsis I, Nikolaou P, Athanaselis S, Stefanidou M, Pistos C, Spiliopoulou C, \& Maravelias, C. (2010) Mass intoxication with Datura innoxia--case series and confirmation by analytical toxicology. Clin. Toxicol. (Phila). 48(2): 143-145.

36. Preissel U \& Hans-Georg P (2002). Brugmansia and Datura: Angel's Trumpets and Thorn Apples. Firefly Books. pp. 124 125.

37. Freye E (2009). Pharmacology and Abuse of Cocaine, Amphetamines, Ecstasy and Related Designer Drugs. Springer Netherlands. 217-218.

38. Arnett AM (1995). Jimson Weed (Datura stramonium) poisoning. Clinical Toxicology Review 18 (3).

39. Tafaghodi M, Hasanzadeh KM, Rahimzadeh M (2003). Isolation and identification of Hyoscymus insanus 
alkaloids. Journal of Medicinal Plants. 2(7): 29-36.

40. Beaman-Mbaya V \& Muhammed SI (1976). Antibiotic Action of Solanum incanum Linnaeus. Antimicrob Agents Chemother. 9(6): 920-924.

41. Thaiyah AG, Nyaga PN, Maribei JM., Mbuthia PG, Ngatia TA \& Nduati D (2010). A experimental solanum incanum L. Poisoning in goats. Bulletin of Animal Health and Production in Africa, 58(1).

42. Hedayati M, Yazdanparast R, Fasihi H \& Azizi F (2003). Anti-tumor Activity of Daphne mucronata Extract and its Effects on TNF-a Receptors and TNF-a Release in Cultured Human Monocytes. Pharmaceutical Biology. 41(3): 194-198.

43. Mahdavi M \& Yazdanparast R (2007). Gnidilatimonoein from Daphne mucronata induces differentiation and apoptosis in leukemia cell lines. Arch. Pharm. Res. 30(2): 177-181.

44. Hedayati M, Yazdanparast R, Yeganeh MZ, Rad LH \& Azizi F (2011). A New Diterpene Extracted from Daphne Mucronata, Effects on Human K562 and CCRF-CEM Cell Lines. Scientific Research. 2(1): 71-75. 